Article

\title{
Assessment of Techno-Functional and Nutraceutical Potential of Tomato (Solanum lycopersicum) Seed Meal
}

\author{
Ramón Maldonado-Torres ${ }^{1,+}{ }^{(\mathbb{C}}$, Jocksan I. Morales-Camacho ${ }^{2,+}{ }^{\circledR}$, Fernando López-Valdez ${ }^{1}$, \\ Luis Huerta-González ${ }^{1}$ and Silvia Luna-Suárez ${ }^{1, * \mathbb{D}}$ \\ 1 Centro de Investigación en Biotecnología Aplicada, Instituto Politécnico Nacional, CIBA-IPN, Tepetitla, \\ Tlaxcala 90700, Mexico; lic.rmaldonadot@gmail.com (R.M.-T.); flopez2072@yahoo.com (F.L.-V.); \\ lhuertaglez@gmail.com (L.H.-G.) \\ 2 Departamento de Ingeniería Química, Alimentos y Ambiental, Universidad de las Américas Puebla, Sta. \\ Catarina Mártir, San Andrés Cholula, Puebla 72810, Mexico; jocksan.morales@udlap.mx \\ * Correspondence: silvials2004@yahoo.com.mx or sluna@ipn.mx; Tel.: +52-555-729-6300 (ext. 87814) \\ + These authors contributed equally to this work.
}

Received: 28 August 2020; Accepted: 13 September 2020; Published: 15 September 2020

check for updates

\begin{abstract}
Tomato (Solanum lycopersicum) is a widely consumed fruit all around the world. The industrial exploitation of tomato generates a lot of waste. Most of the utilization of tomato seeds waste is focused on animal feeding, as well as a food ingredient aimed to increase the protein content, and raw material for some organic bioactive component extraction. The aim of this work was to evaluate the techno-functional properties of tomato seed meal (TSM) and its nutraceutical properties after applying defatting processing (TSMD), and to evaluate the nutraceutical properties after a fermentation processing (TSMDF) by Lactobacillus sp. The results showed that, at alkaline conditions ( $\mathrm{pH}$ 8-9), the techno-functional properties for TSM and TSMD improved. In comparison with TSM, TSMD showed higher water holding capacity (WHC $\approx 32 \%$ ), higher oil holding capacity ( $\mathrm{OHC} \approx 13 \%$ ), higher protein solubility (49-58\%), more than 10 times foaming activity (FA), more than 50 times foam stability (Fst), as well as an improved emulsifying activity (EA) and emulsion stability (Est) wich were better at pH 9. Regarding the nutraceutical properties, afterr $48 \mathrm{~h}$ of fermentation (TSMDF), the antioxidant activity was doubled and a significant increase in the iron chelating activity was also observed. During the same fermentation time, the highest angiotensin-converting enzyme inhibition (ACEI) was achieved (IC50 $73.6 \mu \mathrm{g} / \mathrm{mL}$ ), more than 10 times higher than TSMD, which leads to suggest that this fermented medium may be a powerful antihypertensive. Therefore, the strategy proposed in this study could be an option for the exploitation of tomato wastes.
\end{abstract}

Keywords: tomato seed meal; techno-functional properties; nutraceutical properties; antihypertensive activity; Lactobacillus sp.

\section{Introduction}

Tomato (Solanum lypersicum) is considered as a fruit of high consumption and production all over the world. It is also known that its center of origin comes from the American continent, between Peru and Mexico [1]. In 2018, annual world production of tomato was reported to be around 182,256,458 tons. The main producer countries from America are USA, Mexico, and Brazil with 6.9, 2.5 and 2.25\%, respectively, from total world production [2]. The production is mainly aimed to produce sauces, pastes, juices, puree, and others which generates $3-5 \%$ residues (mainly seed and peel) from raw material [3]. Therefore, the main producer countries from America could be generating between 638,452 and 1,064,072 tons of residue annually, of which tomato seeds represent $60 \%$ [4]. Seeds from tomato are rich in components which have nutritional, techno-functional, and some nutraceutical properties that have been highlighted in recent studies [5,6]. Thus, in order to reduce environmental 
problems by tomato wastes and considering properties from tomato seeds, processors and researches have focused on the use of tomato seeds for animal feeding, as an ingredient for bakery products, and as a raw material for the extraction of oil and proteins [7].

Most alternative uses of seed wastes from tomato are focused on animal feeding due its high protein level content, which is used as a supplement for animal feeding because it improves the production and fat content of cow milk and the growth of sheep [8,9]. Some studies have used tomato pomace meal and tomato seed powder to formulate crackers and bread, respectively. The replacement of wheat flour increased the protein content in new products, but acceptability may be compromised to some extent by changes in the texture and flavor quality of new products $[10,11]$.

The techno-functional properties of proteins from food can be classified according to the interaction they establish with the medium [12]. Hydration properties refer to the protein's ability to interact with water by forming hydrogen bonds. Protein-protein interactions refer to the ability to form bonds or to bind to other proteins present in the medium, either by hydrophilic or hydrophobic interaction. Surface properties refer to the ability to keep two immiscible phases together by directing the fluids towards the interface, resulting in a new structure known as emulsion [13]. Some studies have reported that protein concentrate extracted from tomato seed showed oil absorption capacity, foaming capacity, emulsifying capacity, and stability, although these techno-functional properties were influenced by extraction conditions as reported as temperature, $\mathrm{pH}$, chemical composition of solvent for extraction, and others $[7,14]$. Therefore, the conditions processing for tomato seed meal can affect the techno-functional properties.

The nutraceutical properties of a food are related to the specific composition. Different studies have been reported that the phenolic content from peels of tomato pomace have antioxidant activity by radical scavenging inhibition. Other studies reported that carotenoids from tomato promote health benefits to reduce risks of several diseases, such as Alzheimer's, cardiovascular diseases, and cancer, mainly by lycopene from pulp and peel [7]. With regard to proteins, it refers to the ability of bioactive peptides that are obtained by biochemical fermentation or by enzymatic hydrolysis, and contributes to some physiological benefits as antidiabetes, antiinflammatory, antihypertensive, antioxidative, among others. These properties are related with their structure and its peptide sequence which can act to block the formation of the radical from precursors, such as superoxide or inhibiting angiotensin converting enzyme (for antioxidative effect and antihypertensive affect, respectively) [15]. Recently, some works have identified some antioxidant peptides from tomato isolate from seeds, and the results showed potential scavenging capacity by peptides [16]. A way to obtain bioactive peptides is during fermentation by lactic acid bacteria (as Lactobacillus spp.) which produce proteolytic enzymes and hydrolyze proteins that generate peptides or amino acids with bioactive properties for health benefits [17].

The aim of this work was to evaluate the techno-functional properties of tomato seed meal (TSM) and its nutraceutical properties after applying defatting processing (TSMD) and to evaluate the nutraceutical properties after a fermentation processing (TSMDF) by Lactobacillus spp. For this, techno-functional properties, such as water/oil capacity, protein solubility, foaming capacity, and emulsifying capacity, were measured for TSM and TSMD. Nutraceutical properties, such as DPPH radical scavenging, ABTS radical scavenging, Iron chelating activity, and angiotensin converting enzyme inhibition (ACEI), were determined for TSM, TSMD, and TSMDF.

\section{Results}

\subsection{Sample Preparation and TSM Composition}

The wet method used in this study showed a seed separation efficiency $54.05 \%$. Proximal analysis of TSM showed that protein $(26.93 \pm 0.12 \%)$ and fiber $(26.99 \pm 2.92 \%)$ are majority components into seed meal (Table 1). The phenolic compounds into TSM was $53.38 \mathrm{mg}$ Eq. GA/100g sample. 
Table 1. Proximal composition of TSM sample.

\begin{tabular}{cc}
\hline Component & $(\mathbf{\% )}$ \\
\hline Moisture & $9.93 \pm 0.73$ \\
Ash & $3.92 \pm 0.11$ \\
Proteins & $26.93 \pm 0.12$ \\
Lipids & $14.02 \pm 1.12$ \\
Carbohydrates * & 18.21 \\
Fiber & $26.99 \pm 2.92$
\end{tabular}

Results are mean of triplicate assays, \pm standard deviation. ${ }^{*}$ Result obtained by difference.

Electrophoretic pattern by SDS-PAGE gels showed a higher protein content from TSM and TSMD at $\mathrm{pH}$ from 6-9. As shown in Figure 1, five majority protein bands in both samples (TSM or TSMD) were around 16, 18, 22, 40, and $52 \mathrm{kDa}$ were observed.
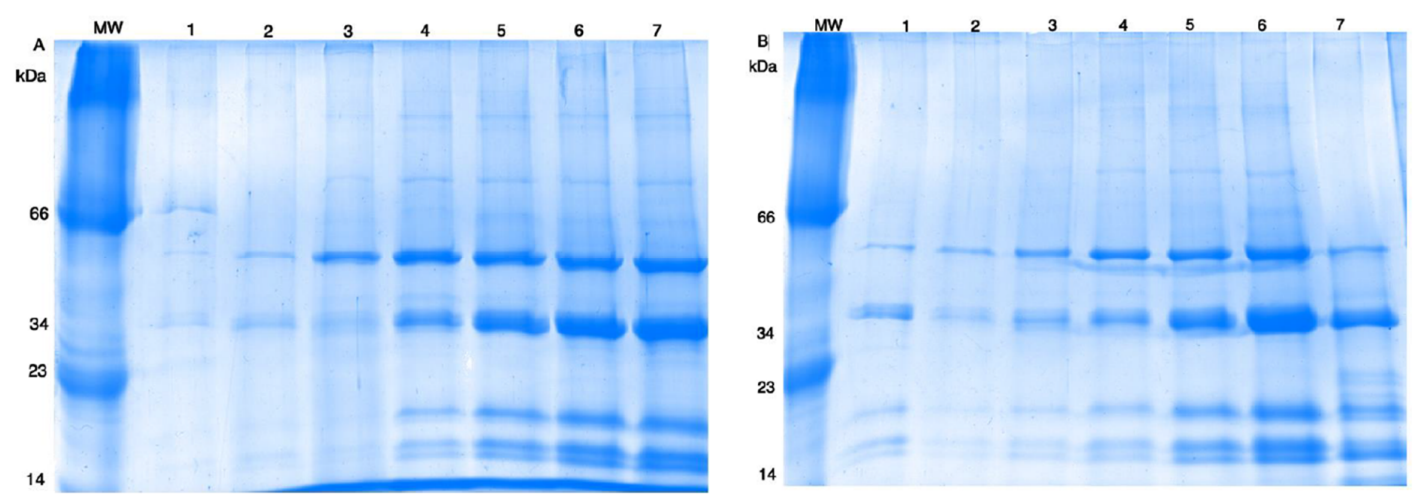

Figure 1. SDS-PAGE, protein solubility at different $\mathrm{pH}$ values. (A) TSM sample; (B) TSMD sample. Lanes: MW, molecular weight; 1, pH 3; 2, pH 4.5; 3, pH 5; 4, pH 6; 5, pH 7; 6, pH 8; 7, pH 9.

\subsection{Techno-Functional Properties}

\subsubsection{Water/Oil Holding Capacity: WHC and OHC}

WHC showed significant differences between TSM and TSMD samples $(p<0.05)$. TSM samples did not show significant differences from $\mathrm{pH} 3$ to 9 (3.18-3.27 g water/g sample). Likewise, TSMD samples showed a higher WHC (4.2-4.3 g water/g sample) from $\mathrm{pH} 6$ to 9, at lower pH WHC slightly lower, but also showed significant differences compared to TSM samples (Supplementary materials Figure S1A). Table 2 shows that, in both samples, WHC is higher as $\mathrm{pH}$ increases.

$\mathrm{OHC}$ was higher in TSMD samples at the $\mathrm{pH}$ value tested $(5,5.5$, and 6$)$, and the results ranged from 2.26 to $2.5 \mathrm{~g}$ oil/g sample, while OHC in TSM ranged from 2 to $2.2 \mathrm{~g}$ oil/g sample. Significant differences $(p<0.05)$ between TSM and TSMD were observed at pH 5.5 and 6 (Table 2 and supplementary Figure S1B). 
Table 2. Techno-functional properties of tomato seed meal (TSM) and tomato seed meal defatted (TSMD)

\begin{tabular}{|c|c|c|c|c|c|c|c|c|}
\hline \multirow{2}{*}{ Techno-Functional Property } & \multicolumn{4}{|c|}{ TSM } & \multicolumn{4}{|c|}{ TSMD } \\
\hline & pH 6 & pH 7 & pH 8 & pH 9 & pH 6 & pH 7 & pH 8 & pH 9 \\
\hline $\mathrm{WHC}^{*}$ & $3.18 \pm 0.11^{\mathrm{a}}$ & $3.25 \pm 0.25^{\mathrm{a}}$ & $3.27 \pm 0.11^{a}$ & $3.26 \pm 0.05^{a}$ & $4.2 \pm 0.2^{b}$ & $4.22 \pm 0.23^{b}$ & $4.27 \pm 0.17^{b}$ & $4.31 \pm 0.31^{b}$ \\
\hline $\mathrm{OHC}^{+}$ & $2 \pm 0.1^{\mathrm{a}}$ & - & - & - & $2.3 \pm 0.15^{b}$ & - & - & - \\
\hline Protein solubility (\%) & $41.6 \pm 1.7^{\mathrm{a}}$ & $45.7 \pm 3.2^{\mathrm{a}}$ & $50.1 \pm 0.2^{b}$ & $55.9 \pm 1.1^{\mathrm{c}}$ & $64.2 \pm 1.1^{\mathrm{d}}$ & $70.5 \pm 0.7^{\mathrm{e}}$ & $79.4 \pm 2.7^{\mathrm{f}}$ & $83.7 \pm 1.21^{f}$ \\
\hline $\mathrm{FA}(\%) "$ & $<2.5^{\mathrm{d}}$ & $<2.5^{\mathrm{d}}$ & $<2.5^{\mathrm{d}}$ & $<2.5^{\mathrm{d}}$ & $16.8 \pm 0.3^{a}$ & $17.01 \pm 0.04^{\mathrm{a}}$ & $26.3 \pm 0.13^{b}$ & $32.1 \pm 0.2^{c}$ \\
\hline Fst (min) & $<0.5^{\mathrm{e}}$ & $<0.5^{\mathrm{e}}$ & $<0.5^{\mathrm{e}}$ & $<0.5^{\mathrm{e}}$ & $1.7 \pm 0.2^{\mathrm{a}}$ & $2.1 \pm 0.01^{b}$ & $29.3 \pm 0.5^{c}$ & $38.1 \pm 0.1^{\mathrm{d}}$ \\
\hline $\mathrm{EA}(\%)^{\alpha}$ & $<4^{\mathrm{h}}$ & $20 \pm 0.01^{\mathrm{a}}$ & $87.5 \pm 0.06^{b}$ & $33.3 \pm 0.02^{c}$ & $6.7 \pm 0.02 \mathrm{~d}$ & $5.0 \pm 0.03^{\mathrm{e}}$ & $83.3 \pm 0.07^{\mathrm{f}}$ & $60.5 \pm 0.06 \mathrm{~g}$ \\
\hline Est $(\%)^{\beta}$ & $<1^{h}$ & $68.2 \pm 0.01^{\mathrm{a}}$ & $68.5 \pm 0.04^{b}$ & $62.0 \pm 0.05^{c}$ & $67.3 \pm 0.09 \mathrm{~d}$ & $71.7 \pm 1.1^{\mathrm{e}}$ & $60.1 \pm 0.07^{\mathrm{f}}$ & $69.8 \pm 0.1^{g}$ \\
\hline
\end{tabular}

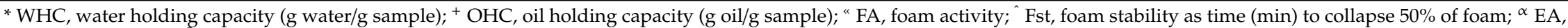

emulsifying activity; ${ }^{\beta}$ Est, Emulsion stability. Different superscripts letters $(\mathrm{a}-\mathrm{h})$ (by rows) indicate significant difference $(p<0.05)$ 


\subsubsection{Protein Solubility}

Protein solubility increased with $\mathrm{pH}$. In both samples, at $\mathrm{pH}$ values from 3 to 5 , protein solubility was lower than 50\% (Supplementary Figure S2). Maximum protein solubility was reached in TSMD samples at $\mathrm{pH} 8$ and 9 with 79.4 and $83.7 \%$, respectively. At the same $\mathrm{pH}$ values, TSM samples showed a protein solubility between 50.1 ( $\mathrm{pH} 8$ ) and $55.9 \%$ (pH 9) (Table 2). These observations were confirmed with SDS-PAGE gels, which showed greater intensity in protein bands as $\mathrm{pH}$ increased, that is at a $\mathrm{pH}$ greater than 6 (Figure 1).

\subsubsection{Foaming Capacity}

No foaming activity (FA) was found in TSM samples. Instead, TSMD showed FA as from pH 5 to 9. A maximum FA was reached at alkaline conditions whereby, at $\mathrm{pH} 8$, it was $26.3 \%$ and at $\mathrm{pH}$ 9 , it was $32.1 \%$ (Table 2). These results are coincident with foam stability (Fst), which was higher at higher $\mathrm{pH}$. Foam half-time at $\mathrm{pH} 8$ was $29.3 \mathrm{~min}$ and at $\mathrm{pH} 9$ was $38.3 \mathrm{~min}$. As can be seen, the foaming capacity of the TSMD sample was higher at alkaline conditions.

\subsubsection{Emulsifying Capacity}

Table 2 shows the results obtained with respect to emulsifying capacity. As can be seen, emulsifying activity (EA) in TSM starting from $\mathrm{pH} 7(20 \%)$ was increasing at $\mathrm{pH} 8$, showing an EA value of $87.5 \%$, whereas at $\mathrm{pH} 9$, the EA value decreased at 33.3\%. Emulsion stability (Est) of TSM samples was around $68 \%$ at $\mathrm{pH} 7-8$, and in a similar way to EA, the Est value was lower $(62 \%)$ at $\mathrm{pH} 9$. Similar results were observed for TSMD samples whereby, at $\mathrm{pH} 8$, a maximum EA value with $87.5 \%$ was reached, and also at $\mathrm{pH} 9$, a lower EA value with $60.5 \%$ was observed (Table 2). TSMD samples showed an Est value from 60.1 to $71.7 \%$, and at $\mathrm{pH} 7$ the maximum Est was value reached. For emulsions prepared using TSM, a reduction stability $\geq 30 \%$ during the first 10 min was observed (Figure 2A). However, for TSMD samples the reduction was lower than $30 \%$ in the same lapse time (Figure 2B). In both TSM or TSMD, at $\mathrm{pH}$ lower than 7, emulsifying activity was affected (Supplementary Figure S3).
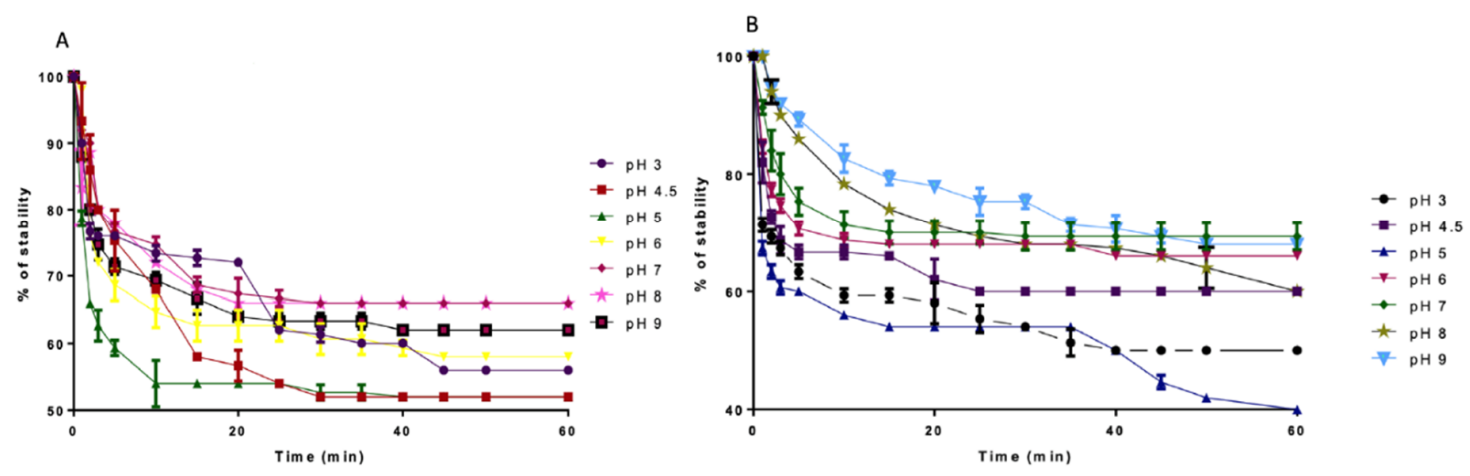

Figure 2. Emulsifying stability at different pH values. (A) TSM sample; (B) TSMD sample.

Mean of triplicate assays \pm standard deviation. Values with different letters within rows indicate significant difference $(p<0.05)$

\subsection{Nutraceutical Properties}

The antioxidant capacity of TSM determined by the DPPH and ABTS methods showed an inhibition percentage of 41.5\% (375.6 $\mu \mathrm{mol}$ Eq Trolox/100 g sample) and 20.2\% (187.8 $\mu \mathrm{mol} \mathrm{Eq} \mathrm{Trolox/100} \mathrm{g}$ sample), respectively. Chelating activity observed for TSM sample was very small $1.1 \%$ (Table 3 ). TSMD showed slightly lower scavenging activity than TSM for DPPH and ABTS reaching 38.9 and $19.3 \%$, respectively. Iron chelating activity showed 2.2 and, $7.9 \%$ of angiotensin converting enzyme inhibition (ACEI). 
Table 3. Nutraceutical properties of tomato seed meal (TSM), tomato seed meal defatted (TSMD), and tomato seed meal defatted and fermented (TSMDF).

\begin{tabular}{|c|c|c|c|c|c|c|}
\hline \multirow{2}{*}{ Sample } & \multicolumn{2}{|c|}{ DPPH } & \multicolumn{2}{|c|}{ ABTS } & \multirow{2}{*}{$\begin{array}{c}\text { Iron Chelating } \\
\text { Activity } \\
(\%)\end{array}$} & \multirow{2}{*}{$\begin{array}{c}\text { ACEI } \\
\begin{array}{c}\text { Inhibition } \\
\%\end{array}\end{array}$} \\
\hline & $\begin{array}{c}\mu \mathrm{M} \mathrm{Eq} \\
\text { Trolox/100 g } \\
\text { Sample }\end{array}$ & $\begin{array}{c}\text { Scavenging } \\
\text { Activity } \\
(\% \mathrm{I})\end{array}$ & $\begin{array}{c}\mu \mathrm{M} \mathrm{Eq} \\
\text { Trolox/100 g } \\
\text { Sample }\end{array}$ & $\begin{array}{l}\text { Scavenging } \\
\text { Activity } \\
(\% \mathrm{I})\end{array}$ & & \\
\hline TSM & $375.6 \pm 4.6^{\mathrm{a}}$ & $41.5 \pm 2.3^{a}$ & $187.8 \pm 2.2^{\mathrm{a}}$ & $20.2 \pm 0.3^{a}$ & $1.1 \pm 0.3^{a}$ & $\begin{array}{c}4.41 \pm 1.3 \\
\mathrm{a}\end{array}$ \\
\hline TSMD & $355.1 \pm 4.8^{b}$ & $38.9 \pm 5.3^{a}$ & $177.3 \pm 1.8^{b}$ & $19.3 \pm 0.05$ & $2.2 \pm 0.01^{b}$ & $7.9 \pm 0.1$ \\
\hline TSMDF (48 h) & $792.5 \pm 5.3^{c}$ & $86.8 \pm 1.3^{b}$ & $419.1 \pm 6.5^{c}$ & $45.6 \pm 0.2^{c}$ & $41.2 \pm 1.1^{c}$ & $83.7 \pm 0.7$ \\
\hline
\end{tabular}

Different superscripts letters a-c (by columns) indicate significant difference $(p<0.05)$.

\subsection{Enhancement of Nutraceutical Properties by Fermentation}

Fermentation kinetic showed that Lactobacillus sp. achieved a maximum growth at $12 \mathrm{~h}$ after fermentation started, and the growth was stationary until $36 \mathrm{~h}$ (Figure 3A). In addition, the content of protein and carbohydrates drastically dropped between 12 and $24 \mathrm{~h}$ of fermentation, where the reduction was around $50 \%$ with respect to initial content (Figure 3A). Also, SDS-PAGE gel shows changes in the molecular weight distribution of proteins throughout the fermentation process, which could be the result of Lactobacillus sp. metabolism (Figure 3B).
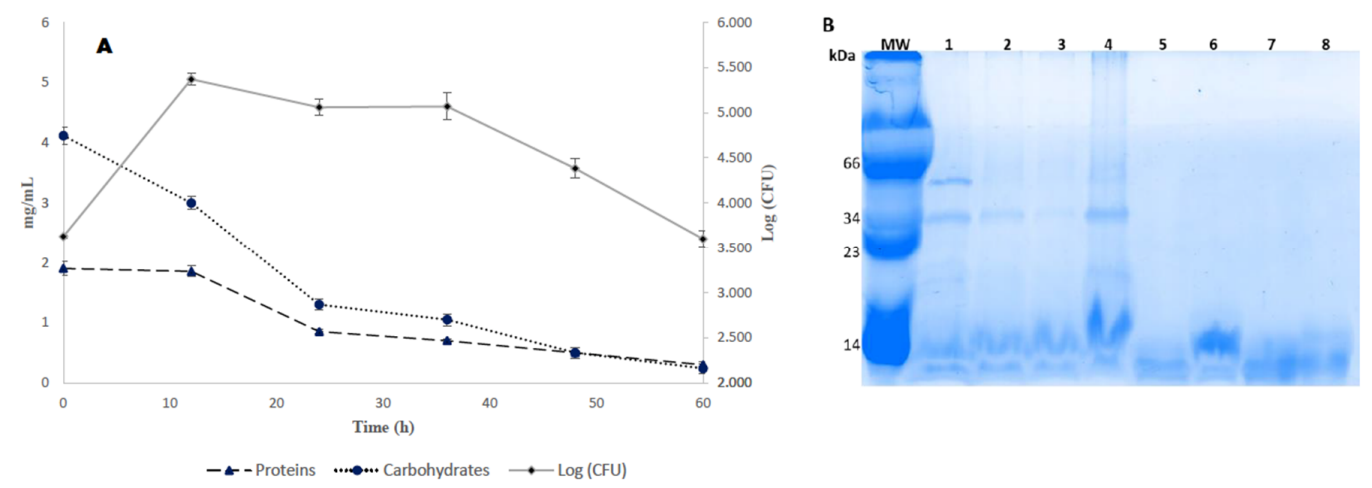

Figure 3. Kinetic of fermentation by Lactobacillus sp. (A) Lactobacillus sp growth and consumption of proteins and carbohydrates. (B) SDS-PAGE protein profile along fermentation process. Lanes: MW, molecular weight; 1, TSMD before sterilization; 2, TSMD sterilized; 3, $0 \mathrm{~h}$ fermentation; $4,12 \mathrm{~h}$ fermentation; 5, $24 \mathrm{~h}$ fermentation; $6,36 \mathrm{~h}$ fermentation; 7, $48 \mathrm{~h}$ fermentation; $8,60 \mathrm{~h}$ fermentation.

After sampling, TSMDF showed better nutraceutical properties after $36 \mathrm{~h}$ of fermentation. The maximum values were registered at $48 \mathrm{~h}$. DPPH and ABTS scavenging activity was almost double that shown by TSM and TSMD. Iron chelating activity and ACEI were 41.2 and $83.7 \%$, respectively. As can be seen, all nutraceutical properties tested were improved during Lactobacillus sp. fermentation (Table 3).

DPPH radical scavenging; ABTS radical scavenging; ACEI, Angiotensin Converting Enzyme inhibition.

All assays were done using $0.01 \mathrm{mg} / \mathrm{mL}$ concentration protein based on the samples.

Mean of triplicate assays \pm standard deviation. Values with different letters within columns indicate significant difference $(p<0.05)$ 


\subsection{In Silico Analysis Biopeptides}

In silico analysis showed that the TSM sample could be a potential precursor of antihypertensive peptides through the fermentation process. ACE inhibitor peptides showed a frequency activity ranged from 23 to 39\%, being the second most predominant nutraceutical property (Figure 4), and in an interesting way DPP-IV inhibitor was the main nutraceutical property suggested by in silico evaluation (Figure 4G). In the proteolysis of the seed storage proteins from tomato, the frequency activity of ACE inhibitor peptides was 32\% (Figure $4 \mathrm{~A}-\mathrm{C}$ ), while a higher ACE inhibitor peptides frequency was obtained for vicilin (PDB6L4M) and aminoaldehyde dehydrogenase (PDB4I8Q) proteins from tomato seed (Figure 4E,F).
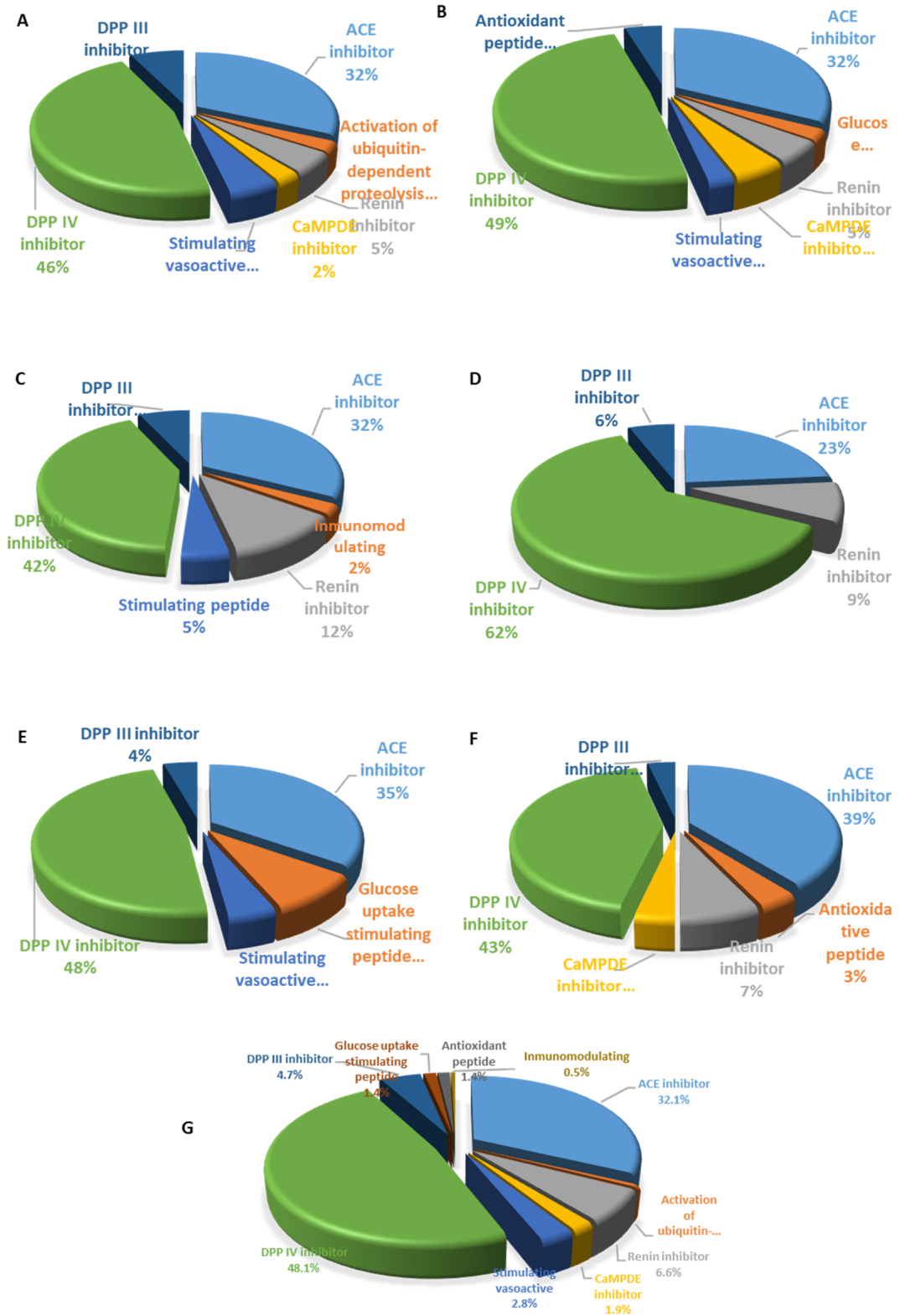

Figure 4. Frequency activity of biopeptides obtained by in silico proteolysis. (A) A5 protein; (B) W4 protein; (C) W15 protein; (D) S6 protein; (E) 4I8Q protein; (F) 6L4M protein; (G) Total frequency activity of peptides generated by hydrolysis in silico analysis using the six proteins from tomato seed. 


\section{Discussion}

\subsection{Techno-Functional Properties}

The separation method used to obtain peel and seeds is relevant to establish the steps of a methodology for the use of tomato wastes. In this sense, the value of seed separation efficiency reported in this study (54.05\%) is higher than 22.4-24.2\% and 51.99\% reported by Shao et al. [18], and higher also than the seed separation efficiency (48.29\%) reported by Kaur et al. [19], who used a mixing tank impeller. It has been reported that wet separation is recommended to acquire seeds, but production of sewage could be an environmental burden [7]. Then, an option could be to recover and recirculate the water during the separation process, as was done in this study.

Techno-functional properties are very important characteristics to maintain the desired texture and flavor of food products. In this sense, WHC and OHC are important to maintain or improve softness, mouthfeel, sensory acceptability, and others. Some studies have reported that defatted tomato seed of tomato pomace has better water absorption capacity, i.e., 3.35-3.45 (g water/g flour), than WHC for soybean protein isolate with $2.39 \mathrm{~g}$ water/g isolate, and even whole tomato seed of tomato pomace showed higher values for WHC (2.6 g water/g flour). In this study, results obtained for TSM and TSMD are around $22-25 \%$ higher for water holding capacity than those reported by Shao et al. for whole and defatted conditions, respectively [14]. Kang et al. [20] determined a water absorption of $2.06 \mathrm{~g}$ water/g flour for defatted soybean flour. Then, TSMD showed two times higher water absorption ( $4.2 \mathrm{~g}$ water/g flour). According to the results obtained, both TSM and TSMD samples could be used as a thickener for food viscous products as sauces or soups, which require WHC ranging from 1.97 to $4.72 \mathrm{~g}$ water/g sample [21].

Higher WHC values in TSMD sample can be explained by the fact that, in this sample, there is a greater content of proteins and their hydrophilic amino acids could be exposed at a pH higher than 5 . Moreover, carbohydrates have hydrophilic regions as polar and charged side chains which can bind to more water molecules [14,22].

$\mathrm{OHC}$ is another important property exploited to formulate sausages, salad dressings, as a meat extender, for flavor retention, and for the enhancement of mouthfeel [23]. As seen in Table 2, TSMD sample showed similar result (2.36 $\mathrm{g}$ oil/ $\mathrm{g}$ sample) as reported by Shao et al. [14]. On the other hand, the results for TSM and TSMD are higher than those reported for soybean flour at $1.36 \mathrm{~g}$ oil/ $\mathrm{g}$ sample. Some studies have reported that $\mathrm{OHC}$ values increase proportionately with the protein content [24]. So, the higher OHC values observed for TSMD could be the result of the defatted process, because reducing the fat proportion increases the protein proportion, which allows non-polar amino acids or hydrophobic domains to be exposed and establish hydrophobic interactions, binding more oil molecules [23].

Protein solubility is important for its techno-functional applications in different foods. As can be seen, TSM and TSMD showed a high solubility at alkaline $\mathrm{pH}$ values (8-9), where the protein solubility is $\mathrm{pH}$ dependent. It is possible that the isoelectric point of proteins into tomato seeds is around $\mathrm{pH} 3-5$. Therefore, by increasing the $\mathrm{pH}$ value, the net charge of the protein is increased as well as the protein solubility and flexibility, resulting in a higher foam capacity at $\mathrm{pH}$ ranging from 6 to 9 . In addition, it is known that foam formation requires protein solubilization in the aqueous phase to form a layer of protein that stabilize the air droplets, which was observed in TSMD at greater pH values [21]. Foam stability (Fst) shown by the TSMD sample is similar to that reported for proteins isolated from defatted of tomato seeds, which showed better foam stability at alkaline conditions ( $\mathrm{pH}$ 9-11) with lower foam stability than TSMD, ranging from 22 to $28 \mathrm{~min}$ as the half-life of foam [14]. Some natural oils and its component as fatty acids have been reported to function as antifoam agents [25]. In this sense, the TSM sample did not show foam capacity, maybe due its oil component.

The protein solubility reported by Elsohaimy et al. [26] for quinoa isolate showed a maximum solubility at $\mathrm{pH} 10$. Other studies reported that the protein solubility shown by amaranth, buckwheat, and quinoa ranged from 2 to $35 \%$ in $\mathrm{pH} 3$ to 5 , in contrast with alkaline conditions, in which the 
protein solubility ranged from 50 to $100 \%$ [27]. In all these sources, the main protein fraction is composed of globulins assembled as a hexamer or trimer, which have been reported as storage proteins in seeds. Each hexamer subunit consists of an acidic $(\approx 32-35 \mathrm{kDa})$ and basic subunit $(\approx 20-24 \mathrm{kDa})$ linking by a disulfide bridge. Trimer globulins, e.g., from soy, are conformed by $\alpha, \alpha^{\prime}$, and $\beta$, with a molecular weight of 72,68 , and $52 \mathrm{kDa}$, respectively [28,29]. These observations are according with the electrophoretic pattern observed in proteins of TSM and TSMD samples, so the majority of proteins observed maybe storage proteins from tomato seeds (Figure 1).

Emulsions mediated by proteins are weak or null at their isoelectric point because, in this condition, protein cannot diffuse to the oil-water interface [30]. This could be the reason why TSM and TSMD showed lower emulsifying activity (EA) at $\mathrm{pH} 3-5$ and a higher EA value as the $\mathrm{pH}$ increased (Table 2 and Supplementary Figure S3).

The results obtained were partially in agreement with Shao et al. [14] who reported an EA at $\mathrm{pH} 9$ of around 40 and $73 \%$ for tomato seed of tomato pomace and defatted tomato seed of tomato pomace, respectively. While for TSM and TSMD the maximum EA was achieved at $\mathrm{pH} 8$ with 87.5 and $83.3 \%$ respectively, both samples showed an emulsifying stability (Est) at $\mathrm{pH} 7$, which is similar to that reported by same authors. Like foaming capacity, EA of TSM and TSMD is pH-dependent because, as $\mathrm{pH}$ increases, EA was increased, and alkaline conditions improved this property in both samples. This may occur because emulsion activity is related to hydrophilic-hydrophobic balance of proteins, the orientation of hydrophilic (to aqueous phase) and lipophilic (to oil phase) amino acids, and the protein solubility which are affected by $\mathrm{pH}$ [23]. Therefore, it is possible that, at $\mathrm{pH} 8$, as proteins from TSM and TSMD showed greater solubility and find conditions to maintain hydrophilic-hydrophobic balance, proteins adopt a structure conformation that allowed for higher emulsifying activity. The EA value for TSM was higher than for TSMD, probably due to the difference in constituents, such as oil or fat, that can also affect emulsifying properties [27].

\subsection{Nutraceutical Properties}

Antioxidant capacity and scavenging activity could be the result of a protein fraction present in TSM and TSMD according to Mechmeche et al. [14], who reported a protein isolate from tomato seed. Valdez-Morales et al. [31] reported an antioxidant capacity in tomato seeds var. saladette by DPPH (92.4 $\mu \mu \mathrm{M}$ Eq Trolox/100 g sample) and ABTS (67.4 $\mu \mu \mathrm{M}$ Eq Trolox/100 g sample) methods, which are almost three and four times lower than the results obtained for TSM and TSMD in this report. The higher DPPH and ABTS scavenging activities observed for TSM could be explained because, in addition to protein fraction, in the TSM sample, there are different components, such as phytosterols and bioactive compounds from tomato seed oil, which act as proton-donating substances. Then, these components promote greater antioxidant activity by a synergic effect $[4,7]$. Moreover, several studies reported that phenolic compounds showed antioxidant activity [5], and in this sense the antioxidant activity shown by TSM also could be influenced by phenolic compounds (53.38 $\mathrm{mg}$ Eq. GA/100g sample), which is similar to phenolic content $(73.8 \mathrm{mg}$ Eq. GA/100g sample) reported for seed from tomato var. saladette [31]. In contrast, in TSMD, as a result of the defatting process, the phenolic content could be reduced, as reported by Sarkar and Kaul [32], which could reinforce that antioxidant activity is primarily prompted by protein content into TSM and TSMD samples.

Metal species as ferrous ion $(\mathrm{Fe} 2+)$ can promote the production of reactive oxygen species, which can damage living systems. In this sense, metal chelating agents may inhibit reactive oxygen species production and prevent damage to DNA, protein, and lipids into cells [33]. TSM and TSMD showed a lower chelating activity (1.1-2.2\%) which was improved by Lactobacillus sp. fermentation, generating TSMDF with greater chelating activity $(41.2 \%)$. Meanwhile, Gunyakti and Asan-Ozusaglam [34] reported DPPH scavenging activity (39.2\%) and iron chelating activity (15.6\%) for supernatants of Lactobacillus gasseri. Chi and Cho [35] reported the iron ion chelating activity of soybean meal fermented by Lactobacillus acidophilus as $30.53 \%$. 
The improvement of scavenging activity and iron chelating activity in TSMDF could be the result of polysaccharides hydrolysis mediated by enzymes during fermentation, and likewise the breakdown of proteins (Figure 3), which allows for the synthesis of different compounds as peptides or free amino acids which can act as chelating agents [36]. In this regard, it has been reported that there is metal chelating potential for amino acids such as methionine, glutamine, glutamic acid, lysine, or arginine within peptides sequences. In addition, other reports indicated that lactic acid bacteria during fermentation promote the synthesis of peptides with antioxidant activity and strong radical scavenging activity [37], which can explain the scavenging activity improved for TSMDF in this study.

Lactic acid bacteria have also been employed in different food sources as seeds to produce angiotensin converting enzyme inhibitor (ACEI) peptides. These peptides are the result of different conditions, such as proteases or strain used, duration of fermentation, $\mathrm{pH}$, and others [38,39]. TSMDF showed almost ten-fold higher ACEI capacity than TSMD. The $\mathrm{IC}_{50}$ value $(73.6 \mu \mathrm{g} / \mathrm{mL})$ of TSMDF at $48 \mathrm{~h}$ after fermentation was higher than $\mathrm{IC}_{50} 180 \mu \mathrm{g} / \mathrm{mL}$ reported for the liquid fermentation of lentils using Lactobacillus plantarum. In this study, the higher ACEI was reached at 48-96 h of fermentation [38].

Interestingly, in silico analysis showed that hydrolysis fermentation could generate DPP-IV inhibitor peptides as in other vegetable sources, such as wheat gluten, lupin seeds, and fermented soybean [40]. The antihypertensive potential shown by TSMDF can be explained by ACEI peptides obtained by Lactobacillus sp. that, according with in silico analysis by BIOPEP, would be hydrolyzed from storage proteins of tomato seeds that showed (as previously mentioned) molecular weights between 20 and $24 \mathrm{kDa}, 32-35 \mathrm{kDa}$, and 52-70 kDa. This agreed with the main polypeptides from tomato seed isolate reported by Mechmeche et al. [17]. This study suggests that nutraceutical properties are promoted by antioxidant peptides, ACE inhibitor peptides, DPP-IV inhibitor peptides, and chelating peptides. It is desirable to continue experimental assays to identify peptide sequences for further applications to generate nutraceutical foods or health-foods.

\section{Materials and Methods}

\subsection{Sample Preparation}

Seeds of tomato var. saladette were obtained from tomato wastes consisted mainly of seeds, peels, and pulp supplied by different industrial dining service companies from the Puebla-Tlaxcala region $\left(19^{\circ} 25^{\prime} 44^{\prime \prime} \mathrm{N}, 98^{\circ} 9^{\prime} 39^{\prime \prime} \mathrm{W}\right)$. The skins and pulp were separated from seeds by the wet method. For this, tomato wastes were immersing in distilled water 1:10 ratio (wastes:water) and mixed for $0.5 \mathrm{~min}$ at $66 \mathrm{rpm}$ in a roller mixer at room temperature. Then, water was drained using a 100 sieve $(150 \mu \mathrm{m})$ to drain water. This process was repeated five times reusing drained water. Finally, tomato seeds were dried in oven at $40^{\circ} \mathrm{C}$ for $12 \mathrm{~h}$. Seeds separation efficiency ( $\eta$ sep) was determined as:

$$
\eta \text { sep }=\frac{\text { Wrec }}{\text { Win }} * 100
$$

where Wrec was the weight of seeds recovered, Win was the weight of sample (seeds, peels, and pulp) before the separation process.

Tomato seed meal (TSM) was obtained by milling the dried seeds with a blade mill. Tomato seed meal defatted (TSMD) was obtained by Soxhlet extraction using hexane at $55{ }^{\circ} \mathrm{C}$ for $6 \mathrm{~h}$ at a ratio 1:10 TSM:hexane $(w / v)$. Then, TSMD was recovered and hexane residues evaporated at $40{ }^{\circ} \mathrm{C}$ under vacuum (Buchi ${ }^{\circledR}$ RE 121 Rotavapor W/461 water bath laboratory).

\subsection{Proximal Composition, Phenolic Compounds, and Proteins}

The proximal composition (fiber, ash, moisture, lipids, and protein content) was determined for TSM using the methods described by AOAC: moisture, 934.06 method; ash, 930.05 method; total fat by the Soxhlet, 903.09 method; protein by the Kjeldahl using a protein conversion factor of $6.25,978.04$ method [41]. Carbohydrate content was determined by the difference. 
Total phenolic compounds were determined by Follin-Ciocalteau method. Briefly, a 10- $\mu \mathrm{L}$ sample was reacted with Follin's reagent and $\mathrm{Na}_{2} \mathrm{CO}_{3}$ (sodium carbonate) and incubated for two hours. After incubation, absorbance was read at $750 \mathrm{~nm}$ (Epoch ${ }^{\mathrm{TM}}$ Microplate Spectrophotometer, Biotek), following the method reported by [42]. Absorbance readings were compared with a gallic acid calibration curve $(\mathrm{mg} / \mathrm{mL})\left(\mathrm{r}^{2}=0.9909\right)$. Results were expressed as mg equivalents of gallic acid/100 $\mathrm{g}$ sample (mg Eq. GA).

Soluble protein concentration was determined by the Bradford method with bovine serum albumin as a standard protein $(\mathrm{mg} / \mathrm{mL})\left(\mathrm{r}^{2}=0.984\right)$ [43]. SDS-PAGE polyacrylamide $(16 \%)$ gel technique was used to analyze protein electrophoretic profile and degraded proteins by hydrolysis during fermentation [44]. For protein extraction, 40mg TSM were added to $200 \mathrm{uL}$ of buffer $0.065 \mathrm{M}$ Tris- $\mathrm{HCl}, 2 \% \mathrm{SDS} \mathrm{pH} 6.8$, and mixed in a vortex for $1 \mathrm{~min}$.

\subsection{Techno-Functional Properties}

\subsubsection{Water Holding Capacity (WHC)}

Water holding capacity of TSM or TSMD was measured at different $\mathrm{pH}$ values in citrate-phosphate buffer ( $\mathrm{pH} 3,4.5,5,6$, and 7) and tris- $\mathrm{HCl}$ buffer ( $\mathrm{pH} 8$ and 9), according to the technique reported by [45] with slight modifications. Then, one g of sample (TSM or TSMD) were mixed and stirred with $10 \mathrm{~mL}$ buffer during $30 \mathrm{~min}$ at room temperature. The slurry was centrifuged at $5000 \times \mathrm{g}$ for $10 \mathrm{~min}$, and the supernatant and sediment were recovered. WHC of TSM and TSMD was calculated according to:

$$
\mathrm{WHC}=\frac{(\mathrm{Ws}-\mathrm{Wds})}{\mathrm{Wi}}
$$

where Ws was the weight of tube with TSM or TSMD sediment, Wds was the weight of tube with dry TSM or TSMD, and Wi was the weight of the dry whole TSM or TSMD samples.

\subsubsection{Oil Holding Capacity (OHC)}

The oil holding capacity of TSM or TSMD was measured at different $\mathrm{pH}$ values, 5.0, 5.5, and 6.0 using soybean oil. Then, $1 \mathrm{~g}$ of sample (TSM or TSMD) was mixed and stirred with $10 \mathrm{~mL}$ soybean oil for $30 \mathrm{~min}$ at room temperature. The slurry was centrifuged at $5000 \times \mathrm{g}$ for $10 \mathrm{~min}$, and the supernatant and sediment were recovered. OHC of TSM and TSMD was calculated according to:

$$
\mathrm{OHC}=\frac{\mathrm{Ws}-\mathrm{WDS}}{\mathrm{Wi}}
$$

where Ws was the weight of tube with TSM or TSMD sediment, Wds was the weight of tube with dry TSM or TSMD, and Wi was the weight of the dry whole TSM or TSMD samples.

\subsubsection{Protein Solubility (PS)}

To determine the solubility of proteins from TSM and TSMD, $0.1 \mathrm{~g}$ of meal was mixed with $1 \mathrm{~mL}$ citrate-phosphate buffer ( $\mathrm{pH} 3,4.5,5,6,7)$ and Tris- $\mathrm{HCl}$ buffer ( $\mathrm{pH} 8$ and 9). The slurries were stirred at $33 \mathrm{rpm}$ during $30 \mathrm{~min}$ in a roller mixer at room temperature. After, the slurries were centrifuged at $5000 \times g$ during $10 \mathrm{~min}$ at room temperature. The protein content in the supernatants was determined by the Bradford method. Samples of each supernatant were analyzed by SDS-PAGE. The protein solubility (PS) was determined according to:

$$
\mathrm{PS} \%=\frac{\mathrm{PCs}}{\mathrm{PCm}} * 100
$$

where PCs was the protein content in supernatants, and PCm was the total protein content into tomato seed meal. 


\subsubsection{Foaming Properties}

One gram of TSM or TSMD was added to citrate-phosphate and Tris-HCL buffers at different $\mathrm{pH}$ values, and the mixture was bubbled for two minutes using an air pump (47L/h). Initial and final foam and foam coalescence were measured as proposed by [46]. The foam activity (FA) of both samples was determined according to:

$$
\mathrm{FA} \%=\frac{\mathrm{Vab}-\mathrm{Vbb}}{\mathrm{Vbb}} * 100
$$

where Vab was the volume of samples after bubbling, and Vbb was the volume of samples before bubbling. The foam stability (Fst) was determined by half-life foam, namely time ( $\mathrm{min}$ ) necessary to reduce $50 \%$ foam volume according to reported by $[11,14]$.

\subsubsection{Emulsifying Properties}

One gram of TSM or TSMD was added to citrate-phosphate and Tris-HCL buffer solutions at different $\mathrm{pH}$ values in a 1:10 ratio (sample:buffer) and mixed for $30 \mathrm{~min}$ at room temperature. After, soybean oil was added in a 40:60 ratio (slurry:oil), and the mixture was stirred for two minutes using a blade mixer until an emulsion was obtained. The volume of the third phase was measured, and the emulsifying capacity (EC) for both samples was obtained according to:

$$
\mathrm{EC} \%=\frac{\mathrm{Vas}}{\mathrm{Vbs}} * 100
$$

where Vas was the volume of the emulsion layer after stirring, and Vbs was the volume of total liquid. The emulsion stability (Est) was evaluated recording Vas during $60 \mathrm{~min}$ after emulsion formation at room temperature.

\subsection{Nutraceutical Properties}

Nutraceutical properties were measured to TMS and TSMD.

\subsubsection{Inhibitory Activity of the 2,2-diphenyl-1-picrylhydrazyl Radical Cation (DPPH)}

The free radical scavenging ability of TSM alcoholic extract (1:10 flour:ethanol 70\%), TSMD alcoholic extract, and TSMDF supernatants was assessed using 2,2-diphenyl-1-picrylhydrazyl radical cation (DPPH) according to the method reported by [5] with slight modifications. Briefly, $20 \mu \mathrm{L}$ of sample adjusted at $0.1 \mathrm{mg} / \mathrm{mL}$ (of protein content) with ethanol were added to $200 \mu \mathrm{L}$ of a $150 \mu \mathrm{mol}$ DPPH solution, and the mixture was left to rest for $30 \mathrm{~min}$. Then, the absorbance at $517 \mathrm{~nm}$ was recorded, against 70\% ethanol as a blank. Results were reported as $\mu \mathrm{M}$ ET (trolox equivalent) and \%I (percent inhibition), according to the following equation:

$$
\% \mathrm{I}=1-\left(\frac{\mathrm{As}}{\mathrm{Ac}}\right) * 100
$$

where As was the absorbance of sample, and Ac was the absorbance of the control which contained $20 \mathrm{uL}$ ethanol instead samples.

\subsubsection{Inhibitory Activity of the Radical Cation of 2,2'azinobis-(3-ethylbenzothialin)-6-sulfonic acid (ABTS)}

The scavenging of 2,2' azinobis-(3-ethylbenzothialin)-6-sulfonic acid (ABTS) was carried out as reported by [17] with some modifications. ABTS $^{+}$was prepared in $2 \mathrm{mM}$ destilled water with $2.45 \mathrm{mM}$ potassium persulfate. The working solution was incubated during $12 \mathrm{~h}$ in the dark at room temperature. Then, the working solution was diluted with $0.1 \mathrm{M}$ phosphates buffer ( $\mathrm{pH}$ 7.4) to obtain an absorbance value to $0.70 \pm 0.02$ at $734 \mathrm{~nm}$. To measure the antioxidant capacity, $10 \mu \mathrm{L}$ of TSM aqueous extract, TSMD aqueous extract, and TSMDF supernatants (adjusted to $1.1 \mathrm{mg} / \mathrm{mL}$ of protein content) was added to $200 \mu \mathrm{L}$ of the ABTS working solution diluted and allowed to react for 6 min after mixing. 
Subsequently, the absorbance was read at $734 \mathrm{~nm}$. Results were reported as $\mu \mathrm{M}$ ET (trolox equivalent) and \% (percent inhibition) according to the following equation:

$$
\% \mathrm{I}=1-\left(\frac{\mathrm{As}}{\mathrm{Ac}}\right) * 100
$$

where As was the absorbance of sample, and Ac was the absorbance of the control which contained $10 \mathrm{uL}$ water samples instead.

\subsubsection{Iron Chelating Activity}

To evaluate the iron chelating activity (ICA) $50 \mu \mathrm{L}$ of $\mathrm{FeSO}_{4}(2 \mathrm{mM})$ was added to $1 \mathrm{~mL}$ of TSM aqueous extract, TSMD aqueous extract, and TSMDF supernatants. The samples were stirred and incubated by $10 \mathrm{~min}$ at room temperature. Then $100 \mu \mathrm{L}$ of ferrozine $(5 \mathrm{mM})$ were added and, afterr $10 \mathrm{~min}$, the absorbance at $562 \mathrm{~nm}$ was read [47]. A blank was prepared using water instead of ferrozine; the results were expressed as \% (percent quelation). The following equation was used to determine ICA (\%):

$$
\% \mathrm{ICA}=1-\left(\frac{\mathrm{As}}{\mathrm{Ac}}\right) * 100
$$

where As was the absorbance of sample and Ac was the absorbance of the control which contained water instead of ferrozine.

\subsubsection{Angiotensin Converting Enzyme Inhibition (ACEI)}

Supernatants obtained at $0,12,24,36,48$, and $60 \mathrm{~h}$ of fermentation were used for measuring the Angiotensin Converting Enzyme inhibitory activity (ACEI) according to reported by [29]. All assays were carried out in triplicate. The ACEI was reported as $\mathrm{IC}_{50}$ value, namely the concentration of hydrolyzed protein that inhibit $50 \%$ of the ACE activity.

\subsection{Enhancement of Nutraceutical Properties by Fermentation}

Lactobacillus sp. strain was obtained from CIBA-IPN collection of microorganisms. Pre-cultures were grown overnight in MRS broth at $37^{\circ} \mathrm{C}$. Subsequently, cells were harvested by centrifugation at $10,000 \times \mathrm{g}$ for $10 \mathrm{~min}$ at $10^{\circ} \mathrm{C}$. The cell pellet was washed with sterile isotonic solution and resuspended in sterile isotonic solution to prepare bacterial suspension.

TSMD 1:5 ratio (sample:distilled water) was used to prepare a fermentation broth supplemented with sucrose $(1.1 \%)$. Shake flask fermentations were performed in Erlenmeyer flasks containing $30 \mathrm{~mL}$ of broth inoculated with $1.3 \times 10^{4} \mathrm{CFU}$ (Colony Forming Units). Cultures were incubated at $37^{\circ} \mathrm{C}$ for $60 \mathrm{~h}$. Samples were taking at $0,12,24,36,48$, and $60 \mathrm{~h}$ of fermentation; were harvested by centrifuging at $10,000 \times \mathrm{g}$ for $10 \mathrm{~min}$ at $10{ }^{\circ} \mathrm{C}$. The supernatants were decanted; cell pellets and supernatants were stored at $-20^{\circ} \mathrm{C}$ for further analysis. The total protein content in all samples harvested was measured by the Bradford method, as well as the carbohydrate content by the phenol-sulfuric method in microplate [48]. Samples of each stage of fermentation were analyzed by SDS-PAGE.

\subsection{In Silico Analysis: Biopeptides}

BIOPEP database was used to evaluate the potential of TSMD as bioactive peptide source through hydrolysis of proteins by proteases from Lactobacillus spp. [49]. For this, Enzyme(s) Action tool (BIOPEP) was used to carry out proteolysis selecting prolyl oligopeptidase (EC 3.4.21.26), Xaa-Pro dipeptidase (EC 3.4.13.9), and proteinase P1 (EC 3.4.21.96) which are enzymes implicated in Lactobacillus spp. metabolism confirmed by the BRENDA database [50]. Four protein sequences from tomato seed were selected from UniProtKB database (http://www.uniprot.org/) with entries: A0A3Q7IWI5 (W15, seed storage protein), A0A3Q7I2A5 (A5, seed storage protein), A0A3Q7I4W4 (W4, seed storage protein), and K4CWS6 (S6, glucocyltransferase), plus two protein sequences from RCSB PDB 
database (http://www.rcsb.org/) with accession numbers 6L4M (vicilin) and 4I8Q (aminoaldehyde dehydrogenase). All of them are proteins involved in seed development or seed germination of tomato.

After in silico digestion, all data collected were analyzed and frequency activity (fac) was determined according to the equation:

$$
\mathrm{fac}=\frac{\mathrm{f}}{\mathrm{F}} * 100
$$

where $\mathrm{f}$ is the number of fragments with a certain bioactivity and $\mathrm{F}$ is the number of total fragments with different bioactivities.

\subsection{Statistical Analysis}

The SAS 7.0 statistic program (SAS Institute Inc., Cary, North Carolina) was used to analyze the data collected from experimental assays. All assays were done in triplicate and results are presented as mean \pm standard deviation (SD). ANOVA analysis and a Tukey test were carried out to observe significant differences $(p<0.05)$.

\section{Conclusions}

The techno-functional properties for TSM and TSMD are higher at alkaline conditions ( $\mathrm{pH} 8-9$ ). In comparison with TSM, TSMD showed higher water holding capacity (WHC $\approx 32 \%$ ), higher oil holding capacity $(\mathrm{OHC} \approx 13 \%)$, higher protein solubility $(49-58 \%)$, more than 10 times foaming activity (FA), more than 50 times foam stability (Fst), as well as improved emulsifying activity (EA) and emulsion stability (Est), which were better at $\mathrm{pH}$ 9. After $48 \mathrm{~h}$ of fermentation, TSMDF doubled its antioxidant activity, a significant increase in its iron-chelating activity was also observed, and angiotensin-converting enzyme inhibition (ACEI) was more than 10 times higher than TSMD. Therefore, the strategy proposed in this study could be an option for exploitation of tomato wastes.

Supplementary Materials: The following are available online at http://www.mdpi.com/1420-3049/25/18/4235/s1, Figure S1: Holding capacity of fluids, Figure S2: Protein solubility of tomato seed meal, Figure S3: Emulsifying activity of tomato seed meal.

Author Contributions: Conceptualization, S.L.-S.; Funding acquisition, S.L.-S.; Supervision, S.L.-S. and F.L.-V.; Writing-review \& editing, S.L.-S., F.L.-V., and L.H.-G.; Project administration, F.L.-V.; Formal analysis, J.I.M.-C.; Software, J.I.M.-C.; Writing—original draft, R.M.-T. and J.I.M.-C.; Investigation, R.M.-T.; Methodology, R.M.-T.; Resources, L.H.-G.; Validation, L.H.-G. All authors have read and agreed to the published version of the manuscript.

Funding: This research was funded by Secretaría de Investigación y Posgrado, Instituto Politécnico Nacional, grant number 20181413.

Acknowledgments: We thanks the Secretaría de Investigación y Posgrado-IPN and Consejo Nacional de Ciencia y Tecnología (CONACYT) for the scholarship to Maldonado-Torres.

Conflicts of Interest: The authors declare no conflict of interest.

\section{References}

1. Blanca, J.; Cañizares, J.; Cordero, L.; Pascual, L.; Diez, M.J.; Nuez, F. Variation revealed by SNP genotyping and morphology provides insight into the origin of the tomato. PLoS ONE 2012, 10, e48198. [CrossRef] [PubMed]

2. FAO. Faostat. Available online: http://www.fao.org/in-action/inpho/crop-compendium/cereals-grains/es/ (accessed on 10 July 2020).

3. Zuorro, A.; Fidaleo, M.; Lavecchia, R. Enzyme-assisted extraction of lycopene from tomato processing waste. Enzyme Microb. Tech. 2011, 49, 567-573. [CrossRef] [PubMed]

4. Zhang, Y.; Pan, Z.; Venkitasamy, C.; Ma, H.; Li, Y. Umami taste amino acids produced by hydrolyzing extracted protein from tomato seed meal. LWT-Food Sci. Technol. 2015, 62, 1154-1161. [CrossRef]

5. Elbadrawy, E.; Sello, A. Evaluation of nutritional value and antioxidant activity of tomato peel extracts. Arab. J. Chem. 2016, 9, S1010-S1018. [CrossRef]

6. Soji, D.; Garg, S.; Bawa, A. Functional properties of seed meals and protein concentrates from tomato-processing waste. J. Food Sci. 2002, 2997-3001. [CrossRef] 
7. Lu, Z.; Wang, J.; Gao, R.; Ye, F.; Zhao, G. Sustainable valorization of tomato pomace: A comprehensive review. Trends Food Sci. Tech. 2019, 86, 172-187. [CrossRef]

8. Abdollahzadeh, F.; Pirmohammadi, R.; Farhoomand, P.; Fatehi, F.; Pazhoh, F.F. The effect of ensiled mixed tomato and apple pomace on olstein dairy cow. Ital. J. Animal Sci. 2010, 9. [CrossRef]

9. Gebeyew, K.; Animut, G.; Urge, M.; Feyera, T. The effect of feeding dried tomato pomace and concentrate feed on body weight change, carcass parameter and economic feasibility on hararghe highland sheep, Eastern Ethiopia. J. Vet. Sci. Tech. 2014, 6, 217. [CrossRef]

10. Isik, F.; Topkaya, C. Effects of tomato pomace supplementation on chemical and nutritional properties of crackers. Ital. J. Food Sci. 2016, 28, 525-535. [CrossRef]

11. Sogi, D.S.; Sidhu, J.S.; Arora, M.S.; Garg, S.K.; Bawa, A.S. Effect of tomato seed meal supplementation on the dough and bread characteristics of wheat (PBW343) flour. Int. J. Food Prop. 2002, 5, 563-571. [CrossRef]

12. Mechmeche, M.; Kachouri, F.; Ksontini, H.; Setti, K.; Hamdi, M. Bioprocess development and preservation of functional food from tomato seed isolate fermented by kefir culture mixture. J. Food Sci. Tech. Mys 2018, 55, 3911-3921. [CrossRef] [PubMed]

13. Zayas, J.F. Solubility of Proteins. In Functionality of Proteins in Food, 1st. ed.; Zayas, J.F., Ed.; Springer: New York, NY, USA, 1997; pp. 6-75.

14. Shao, D.; Atungulu, G.G.; Pan, Z.; Yue, T.; Zhang, A.; Fan, Z. Characteristics of isolation and functionality of protein from tomato pomace produced with different industrial processing methods. Food Bioprocess Tech. 2014, 7, 532-541. [CrossRef]

15. Hati, S.; Patel, N.; Sakure, A.; Mandal, S. Influence of whey protein concentrate on the production of antibacterial peptides derived from fermented milk by lactic acid bacteria. Int. J. Pept. Res. Ther. 2018, 24, 87-98. [CrossRef]

16. Aderinola, T.A.; Fagbemi, T.N.; Enujiugha, V.N.; Alashi, A.M.; Aluko, R.E. In vitro antihypertensive and antioxidative properties of alcalase-derived Moringa Oleifera seed globulin hydrolysate and its membrane fractions. J. Food Process Pres. 2019, 43, e13862. [CrossRef]

17. Mechmeche, M.; Kachouri, F.; Ksontini, H.; Hamdi, M. Production of bioactive peptides from tomato seed isolate by Lactobacillus plantarum fermentation and enhancement of antioxidant activity. Food Biotechnol. 2017, 31, 94-113. [CrossRef]

18. Shao, D.; Atungulo, G.G.; Pan, Z.; Yue, T.; Zhang, A.; Chen, X. Separation methods and chemical and nutritional characteristics of tomato pomace. T. ASABE 2013, 56, 261-268. [CrossRef]

19. Kaur, D.; Sogi, D.S.; Garg, S.K.; Bawa, A.S. Flotation-cum-sedimentation system for skin and seed separation from tomato pomace. J. Food Eng. 2005, 71, 341-344. [CrossRef]

20. Kang, S.W.; Rahman, M.S.; Kim, A.N.; Lee, K.Y.; Park, C.Y.; Kerr, W.L.; Choi, S.G. Comparative study of the quality characteristics of defatted soy flour treated by supercritical carbon dioxide and organic solvent. J. Food Sci. Technol. 2017, 54, 2485-2493. [CrossRef]

21. Chandi, K.; Sogi, D. Functional properties of rice bran protein concentrates. J. Food Eng. 2007, 79, 592-597. [CrossRef]

22. Awolu, O.O.; Osemeke, R.O.; Ifesan, B.O.T. Antioxidant, functional and rheological properties of optimized composite flour, consisting wheat and amaranth seed, brewers' spent grain and apple pomace. J. Food Sci. Technol. 2016, 53, 1151-1163. [CrossRef]

23. Mao, X.; Hua, Y. Composition, structure and functional properties of protein concentrates and isolates produced from walnut (Juglans regia L.). Int. Mol. Sci. 2012, 13, 1561-1581. [CrossRef]

24. Ogunwolu, S.O.; Henshaw, F.O.; Mock, H.P.; Santros, A.; Awonorin, S.O. Functional properties of protein concentrates and isolates produced from cashewnut (Anacardium occidentale L.). Food Chem. 2009, 115, 852-858. [CrossRef]

25. Kougias, P.G.; Tsapekos, P.; Boe, K.; Angelidaki, I. Antifoaming effect of chemical compounds in manure biogas reactors. Water Res. 2013, 47, 6280-6288. [CrossRef]

26. Elsohaimy, S.A.; Refaay, T.M.; Zaytoun, M.A.M. Physicochemical and functional properties of quinoa protein isolate. Ann. Agric. Sci. 2015, 60, 297-305. [CrossRef]

27. Janssen, F.; Pauly, A.; Romboust, I.; Jansens, K.J.A.; Deleu, L.J.; Delcour, J.A. Proteins of amaranth (Amaranthus spp.), buckwheat (Fagopyrum spp.), and quinoa (Chenopodium spp.): A food science and technology perspective. Comp. Rev. Food Sci. Saf. 2019, 16, 39-58. [CrossRef] 
28. Liu, M.; Lee, D.S.; Damodaran, S. Emulsifying properties of acidic subunits of soy 11S globulin. J. Agric. Food Chem. 1999, 47, 4970-4975. [CrossRef] [PubMed]

29. Luna-Suárez, S.; Medina-Godoy, S.; Cruz-Hernández, A.; Paredes-López, O. Modification of the amaranth $11 \mathrm{~S}$ globulin storage protein to produce an inhibitory peptide of the Angiotensin I Converting Enzyme, and its expression in Escherichia coli. J. Biotechnol. 2010, 148, 240-247. [CrossRef] [PubMed]

30. Shevkani, K.; Singh, N.; Rana, J.C.; Kaur, A. Relationship between physicochemical and functional properties of amaranth (Amaranthus hypochondriacus) protein isolates. Int. J. Food Sci. Tech. 2014, 49, 541-550. [CrossRef]

31. Valdez-Morales, M.; Espinosa-Alonso, L.G.; Espinoza-Torres, L.C.; Delgado-Vargas, F.; Medina-Godoy, S. Phenolic content and antioxidant and antimutagenic activities in tomato peel, seeds, and byproducts. J. Agric. Food Chem. 2014, 62, 5281-5289. [CrossRef] [PubMed]

32. Sarkar, A.; Kaul, P. Evaluation of tomato processing by-products: A comparative study in a pilot scale setup. J. Food Process Eng. 2014, 299-307. [CrossRef]

33. Kehrer, J. The Haber-Weiss reaction and mechanisms of toxicity. Toxicology 2000, 149, 43-50. [CrossRef]

34. Gunyakti, A.; Asan-Ozusaglam, M. Lactobacillus gasseri from human milk with probiotic potential and some technological properties. LWT 2019, 109, 261-269. [CrossRef]

35. Chi, C.; Cho, S.J. Improvement of bioactivity of soybean meal by solid-state fermentation with Bacillus amyloliquefaciens versus Lactobacillus spp. and Saccharomyces cerevisiae. LWT Food Sci. Technol. 2019, 68, 619-625. [CrossRef]

36. Luz, C.; Izzo, L.; Graziani, G.; Gaspari, A.; Ritieni, A.; Mañes, J.; Meca, G. Evaluation of biological and antimicrobial properties of freeze-dried whey fermented by different strains of Lactobacillus plantarum. Food Funct. 2018, 9, 3688-3697. [CrossRef]

37. Hur, S.J.; Lee, S.Y.; Kim, Y.C.; Choi, I.; Kim, G.B. Effect of fermentation on the antioxidant activity in plant-based foods. Food Chem. 2014, 160, 346-356. [CrossRef]

38. Torino, M.I.; Limón, R.I.; Martínez-Villaluenga, C.; Mäkinen, S.; Pihlanto, A.; Vidal-Valverde, C.; Frias, J. Antioxidant and antihypertensive properties of liquid and solid state fermented lentils. Food Chem. 2013, 136, 1030-1037. [CrossRef]

39. Walters, M.E.; Esfandi, R.; Tsopmo, A. Potential of food hydrolyzed proteins and peptides to chelate iron or calcium and enhance their absorption. Foods 2018, 7, 172. [CrossRef]

40. Liu, R.; Cheng, J.; Wu, H. Discovery of food-derived dipeptidyl peptidase IV inhibitory peptides: A review. Int. J. Mol. Sci. 2019, 20, 463. [CrossRef]

41. Association of Official Analytical Chemists (AOAC). Official Methods of Analysis of AOAC International, 15th ed.; AOAC International: Gaithersburg, MD, USA, 1990.

42. Ayyash, M.; Johnson, S.K.; Liu, S.Q.; Mesmary, N.; Dahmani, S.; Al Dhaheri, A.S.; Kizhakkayil, J. In Vitro investigation of bioactivities of solid-state fermented lupin, quinoa and wheat using Lactobacillus spp. Food Chem. 2019, 275, 50-58. [CrossRef]

43. Barbosa, H.; Slater, N.K.H.; Marcos, J.C. Protein quantification in the presence of poly (ethylene glycol) and dextran using the bradford method. Anal. Biochem. 2009, 395, 108-110. [CrossRef]

44. Laemmli, U.K. Cleavage of structural proteins during the assembly of the head of bacteriophage T4. Nature 1970, 227, 680-685. [CrossRef] [PubMed]

45. Coelho, M.S.; de las Mercedes Salas-Mellado, M. How extraction method affects the physicochemical and functional properties of chia proteins. LWT 2018, 96, 26-33. [CrossRef]

46. Prosekov, A.; Babich, O.; Kriger, O.; Ivanova, S.; Pavsky, V.; Sukhikh, S.; Yang, Y.; Kashirskih, E. Functional properties of the enzyme-modified protein from oat bran. Food Biosci. 2018, 24, 46-49. [CrossRef]

47. Morel, I.; Lescoat, G.; Cogrel, P.; Sergent, O.; Pasdeloup, N.; Brissot, P.; Cillard, J. Antioxidant and iron-chelating activities of the flavonoids catechin, quercetin and diosmetin on iron-loaded rat hepatocyte cultures. Biochem. Pharmacol. 1993, 45, 13-19. [CrossRef]

48. Albalasmeh, A.A.; Asmeret, A.B.; Teamrat, A.G. A new method for rapid determination of carbohydrate and total carbon concentrations using UV spectrophotometry. Carbohydr. Polym. 2013, 97, 253-261. [CrossRef] [PubMed] 
49. Minkiewicz, P.; Iwaniak, A.; Darewicz, M. BIOPEP-UWM database of bioactive peptides: Current opportunities. Int. J. Mol. Sci. 2019, 20, 5978. [CrossRef]

50. Schomburg, I.; Chang, A.; Schomburg, D. BRENDA, enzyme data and metabolic information. Nucleic Acid. Res. 2002, 30, 47-49. [CrossRef]

Sample Availability: Samples of the seed meal are available from the authors.

(C) 2020 by the authors. Licensee MDPI, Basel, Switzerland. This article is an open access article distributed under the terms and conditions of the Creative Commons Attribution (CC BY) license (http://creativecommons.org/licenses/by/4.0/). 